\title{
Impact of The Climate Change to The Small-Scale Fisheries and Their Adaptation in Kota Belud, Sabah
}

Nurrul Fazlina Osman, Jain Yassin, Jamal Gabir, Suhailie Bakrin

To Link this Article: http://dx.doi.org/10.6007/IJARBSS/v11-i6/10115

DOI:10.6007/IJARBSS/v11-i6/10115

Received: 04 April 2021, Revised: 30 April 2021, Accepted: 16 May 2021

Published Online: 03 June 2021

In-Text Citation: (Osman et al., 2021)

To Cite this Article: Osman, N. F., Yassin, J., Gabir, J., \& Bakrin, S. (2021). Impact of The Climate Change to The Small-Scale Fisheries and Their Adaptation in Kota Belud, Sabah. International Journal of Academic Research in Business and Social Sciences, 11(6), 240-252.

\section{Copyright: @ 2021 The Author(s)}

Published by Human Resource Management Academic Research Society (www.hrmars.com)

This article is published under the Creative Commons Attribution (CC BY 4.0) license. Anyone may reproduce, distribute, translate and create derivative works of this article (for both commercial and non-commercial purposes), subject to full attribution to the original publication and authors. The full terms of this license may be seen at: http://creativecommons.org/licences/by/4.0/legalcode

Vol. 11, No. 6, 2021, Pg. 240 - 252

Full Terms \& Conditions of access and use can be found at http://hrmars.com/index.php/pages/detail/publication-ethics 


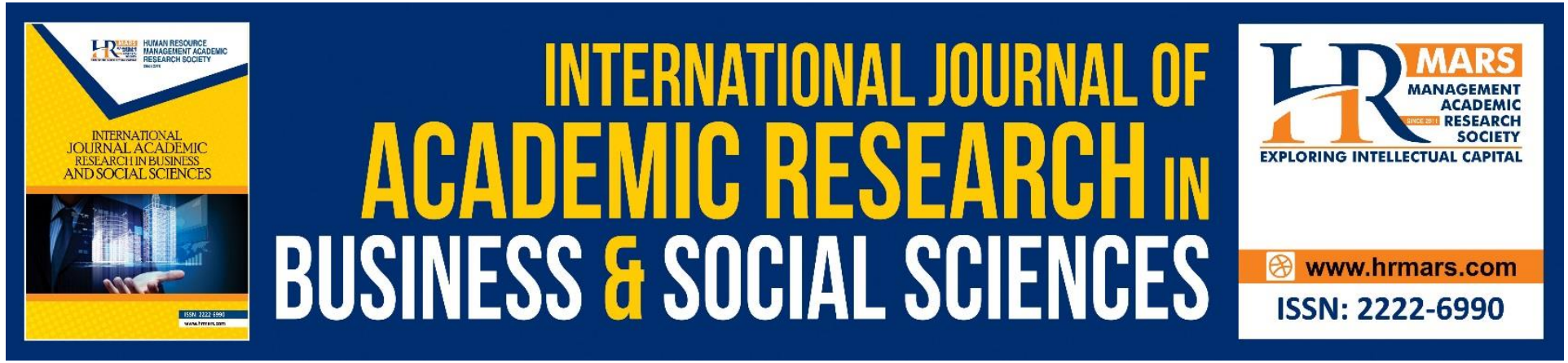

\title{
Impact of The Climate Change to The Small-Scale Fisheries and Their Adaptation in Kota Belud, Sabah
}

\author{
Nurrul Fazlina Osman \\ Borneo Research Marine Institute, Universiti Malaysia Sabah (UMS), Kota Kinabalu, Sabah, \\ Malaysia
}

Jain Yassin

Faculty of Business and Management, Universiti Teknologi Mara (UiTM) Sabah Branch, Kota Kinabalu, Sabah, Malaysia

Jamal Gabir

Institute Borneo Studies (IBS), University College Sabah Foundation (UCSF), Jalan empelang, Kota Kinabalu, Sabah, Malaysia

\section{Suhailie Bakrin}

Faculty of Business and Management, Universiti Teknologi Mara (UiTM) Sabah Branch, Kota Kinabalu, Sabah, Malaysia

\section{Abstract}

Social studies on small-scale fisheries are important first-stage metrics for understanding the impact of the fishermen's livelihood towards climate change. This approach is important for regions where management resources are limited. This study aims to access the climate change awareness and explore the ecological and social resilience and their potential adaptability related the climate change among the small-scale fisheries in Kota Belud, Sabah. This study using the structural interview with ten respondents were selected in Usukan and Pintasan of Kota Belud coastal area. The results show that the small-scale fisheries are not aware of the impact of climate change on their livelihood. Moreover, the sea produce was getting smaller and farther from the coastal area and most of them demonstrate weak adaptability toward climate change impact. Thus, fast action is required from the government and other stakeholders to constructing the best adaptation strategies to overcome the rising climate change.

Keywords: Small-scale Fisheries, Climate Change, Livelihood, Ecological And Social Resilience, Sabah. 


\section{Introduction}

Marine capture fisheries have been recognised globally for their significant roles in the food supply, food security, and income generation. For instance, in Malaysia fisheries sector has produced $1.85 \mathrm{mt}$ productions with a value estimated at USD 3.3 billion or RM 14.5 billion (Department of Fisheries Malaysia, 2020). To date, globally, out of 35 million fishers are classified as small-scale fishers and it is estimated that another 20 million people participate in the post-harvest sector on a small scale (FAO, 2021). Although there's no official record of the number of small-scale fishers in Malaysia, past nearby ponders have reliably found that small-scale fishers constitute more than $65 \%$ of the by and large fishermen populace (Omar et al., 2012; Ramli et al., 2013).

In Malaysia, Sabah was recognised as one of the highest contributors to the national fisheries sector for many years with an average of 208,159.34 metric tonnes per year worth an estimated 1 billion ringgit from the period 2012 to 2018 (Insitute for Development Studies, 2020). Moreover, Sabah is the second largest state in Malaysia and has a rich treasure of natural resources. Besides having a very fertile land area for agriculture, the coastal area has a lot of marine biodiversities, from the coast to the deep ocean. The uniqueness of its natural resources also makes Sabah highly renowned for its natural and cultural tourism industry. Amongst the areas that have such privileges in Sabah is Kota Belud. The strategic geographical location of Kota Belud district which has oceans in the northwest and highlands in the southeast makes Kota Belud among the unique and potential areas of agriculture, fisheries, and tourism. Several locations in Kota Belud district such as Mantanani Island, Tamu Besar Kota Belud, and Polumpong Melangkap that are located at the foot of Mount Kinabalu are already recognized and famous not only at the national level but also at the international level.

Howbeit, the main concern by society at large is the environmental stress due to the degradation of the ecosystem and natural resources (Yassin et al., 2021). Therefore, the sustainability of the fisheries sector is determined by the environmental factor especially climate change. The rising of global temperatures by drastic changes in weather and climate can be seen through extreme changes in rainfall, resulting in more sudden floods, droughts, or intense rain, as well as more frequent and severe heat waves making life miserable especially for those who are trapped in poverty. The impact of climate change threatens people with flooding, food insecurity, economic losses, water scarcity, infectious diseases, extreme heat, and displacement (Magawata \& Ipinjolu, 2014). Hence, the negative effect of climate change will affect the productivity and profitability levels of fishers, especially smallscale fisheries.

Realising the importance of the environmental and social in ensuring the sustainability of small-scale fishers, this study attempts to concentrate on achieving two objectives. First, to evaluate the climate change awareness of small-scale fisheries. Second, to assess the ecological and social resilience and their potential adaptability related the climate change. The discussion of this paper provides a better understanding and insights on the impact of climate change on small-scale fisheries and their adaptation to Kota Belud.

\section{Background of the Study}

The population of Kota Belud district consists of multiculturalism, and the majority are from the Kadazan/Dusun ethnic group, Bajau Samah, Iranun, Ubian, and Chinese. While the economy is dependent on the agriculture and fishery sectors. Nevertheless, due to its lower 
position from sea level and climate change, Kota Belud is always facing environmental issues especially frequent threats of flooding.

Kota Belud is a federal consistuency in Sabah, Malaysia and is currently divided into four districts, namely Pintasan (formerly known as Tempasuk), Tempasuk, Usukan and Kadamaian. Kota Belud is situated less than 50 kilometers from the Kota Kinabalu and covers an area of 1,372 square kilometers which consists of 173 registered villages as in 2021. Kota Belud are divided into 20 mukims, namely Kulambai, Ambong, Sembirai, Kota Belud, Kedatuan, Pirasan, Tempasuk, Rosok, Taun Gusi, Keguraan, Rampayan, Dudar, Kelawat, Kinasaraban, Lasau, Mangkulat, Woriou, Taginambur, Kebayau and Kadamaian (Kota Belud Liaison Office, 2021). Each district has their own district officers and a total of 150 head villagers.

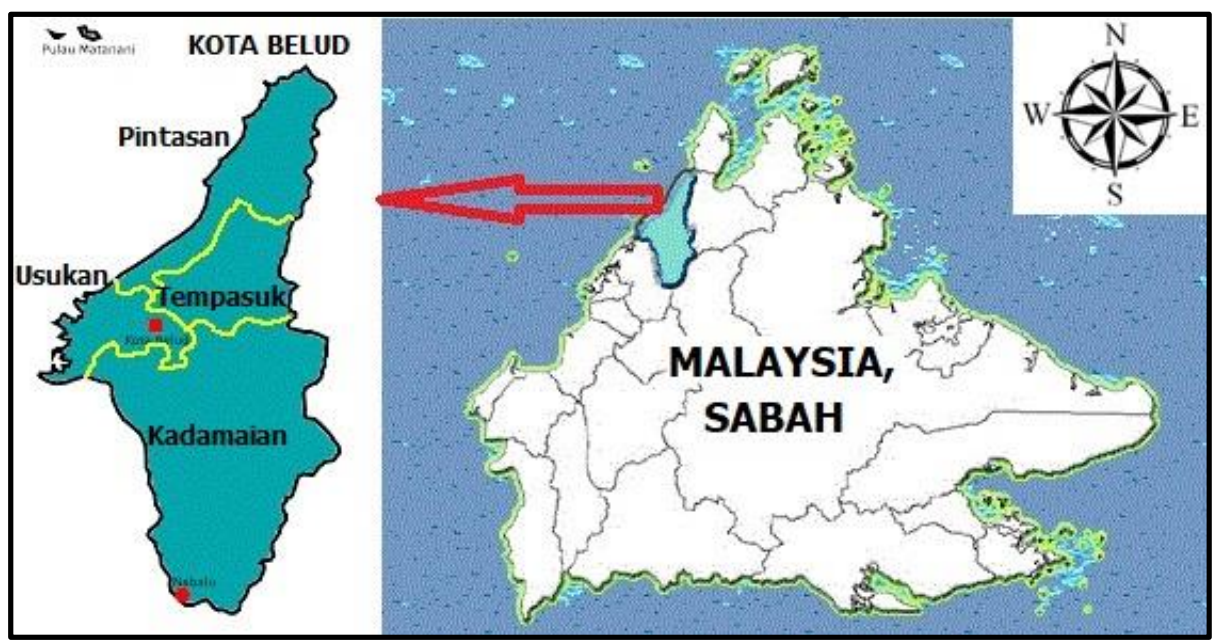

Figure 1. Pintasan and Usukan in Kota Belud, Sabah, Malaysia

(Source: Modified from sabah.edu.my)

\section{Literature Review}

Impact on Climate Change on Small Scale Fishers

Changes in climatic factors modify the efficiency and dissemination of marine and freshwater fish species, contrarily influencing the vocations of fishery-dependent communities around the world. A study in Zimbabwe demonstrated that small-scale fishing is the community's essential vocation movement. More than $62 \%$ of fishermen expressed that fishing income is declining, owing to declining fish catches. Of members, $98 \%$ perceived nourishment buys as the essential source of nourishment. In this manner, $78 \%$ of the small-scale fishers see their family units to be nourishment uncertain due to declining livelihoods from fisheries (Muringai et al., 2019).

Another study by Islam et al (2020) was embraced to evaluate the impacts of climate alter on the hilsa shad fishery system and the versatile measures taken by fisher communities in Bangladesh's coastal locale. It found that climate alter has colossal unfavorable effects on the country's most impoverished fishing communities by affecting their job resources, particularly by diminishing the hilsa stock upon which their employments are based. Climate alter has potential impacts on the life cycle stages and relocation designs of hilsa. Besides, harm to physical resources, fishing equipment, houses, and framework, for occurrence, escalating these communities' helplessness.

In Malaysia, Muhammad et al (2016) concluded that Malaysian small-scale fishermen are also experiencing the impacts of climate change similar to other countries in the world. This impact of climate change has brought negative implications towards several community 
groups and the small-scale fishermen are one of them. Climate change is found to have increased several risks associated with fishing activities, affect their productivity, health, and damage to public facilities.

\section{Adaptation of Small-Scale Fishers towards Climate Change}

Climate change has been shown to reduce fishermen's productivity, put their lives in jeopardy, harm their physical infrastructure, expose them to health issues, and reduce their food supply, however, there is a range of attempts that can be made at the individual level to reduce and deferred the effects, the most important of which is to improve fishermen's adaptability. Shaffril et al. (2017) suggested that social adaptation can be accelerated by concentrating on six key issues: (1) reducing risks associated with fishing routines, (2) improving social relationships, (3) managing fishermen's climate change awareness, (4) promoting the community's learning of alternative skills, (5) involving fishermen in climate change adaptation preparation, and (6) credit is accessible to fishermen. Figure 2 shows a simple framework to determine the potential impact and adaptive capacity of the small-scale fishers adapted. Lighter grey represents qualitative data through in-depth interviews. The dark grey represents the score of fishes or sea produce increase or decrease.

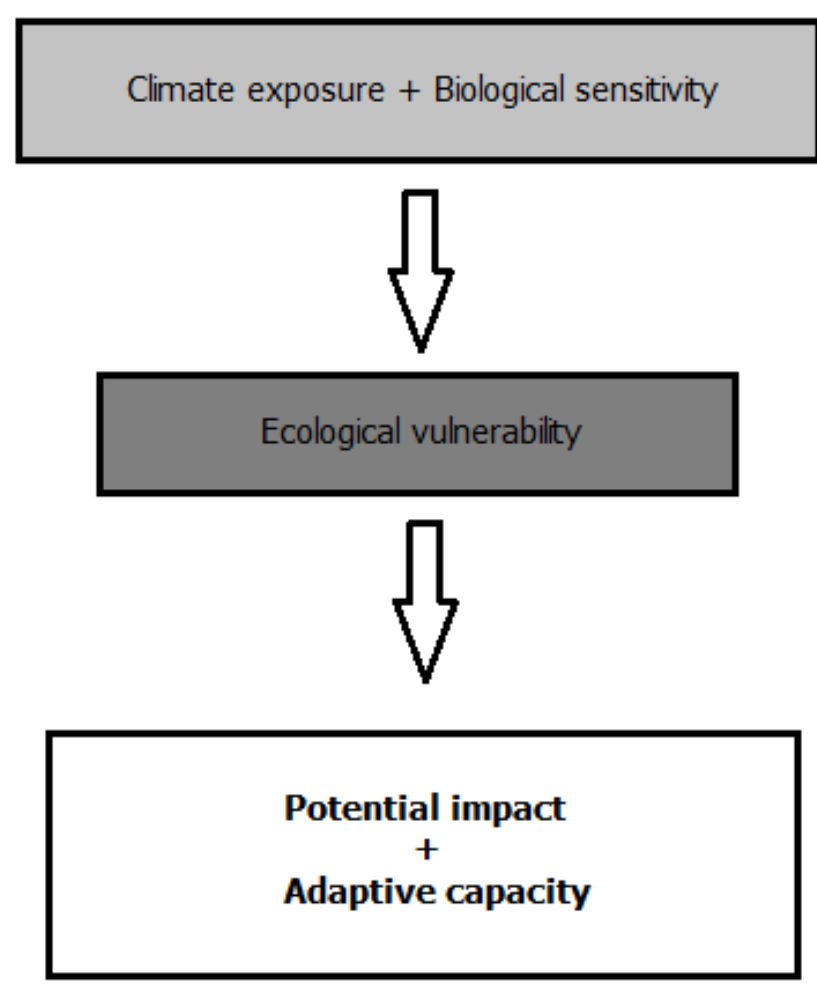

Figure 2. Simple conceptual framework adapted from Marshall et al. (2013) for assessing vulnerability to climate change

\section{Research Methodology}

This study adopted a qualitative research approach with an in-depth interview. Due to restrictive measures imposed by the authorities during the pandemic, direct or face-to-face interview for the survey was limited, thus the interview conducted in a small circle of people. Focus group discussion was implemented to the specific group of people so the activity of generating and sharing ideas can relate to them with the new policy, idea, or issue (Breen, 2007). 
A total of seven women and three men fisheries were selected through a nonprobability sampling technique (purposive sampling). The interview was conducted in March 2021. The main criteria for the selection of research participants were, a) the participants were identified doing fishers-related activities. b) categorised as small-scale fisheries. Smallscale fisheries or known as artisanal fishers refers to the community that fishing with a small amount of capital and energy, fishing for their households, have small fishing vessels (if any), short fishing trips, close to the coastal line, and mainly of local consumption. They can be categories as full-time or part-time, or just seasonally, they are also often targeted on supplying fish and fishery products to local and domestic markets (Staples et al., 2004). c) are categorised under the B40 group as those with a household income of less than RM4,360 per month (Khazanah Research Institute Report, 2017).

The semi-structured questionnaire is divided into three themes, namely, a) climate change awareness b) fishers' ecological and social resilience c) fishers' potential adaptability. This allows the interviews to be conducted in 15-20 minutes in an informative conversation. This study follows the qualitative method by transcribed and analysed the interview inputs using the thematic analysis approach (Che Omar et al., 2020; Abbas et al., 2020). The demographics of the participates are summarised in Table 1.

Table 1. Demographic Analysis of Research Participants

\begin{tabular}{llll}
\hline $\begin{array}{l}\text { Demographic } \\
\text { Characteristics }\end{array}$ & Sub-Level & Count $\mathbf{n = 1 0}$ & Percentage (\%) \\
\hline Age & $26-35$ & 1 & 10 \\
& $36-45$ & 2 & 20 \\
& $46-55$ & 5 & 50 \\
& $56-60$ & 2 & 20 \\
\hline Income & 500 and below & 2 & 20 \\
& $501-1000$ & 3 & 30 \\
& $1001-2000$ & 5 & 50 \\
\hline Location (district) & Usukan (Kg. Song- & 4 & 40 \\
& Song, Kg. Buah & & \\
& $\begin{array}{l}\text { Pandai) } \\
\text { Pintasan (Kg. Pantai }\end{array}$ & 6 & 60 \\
& Emas, Kg. Liang) & & \\
\hline
\end{tabular}

Table 1 summarises the distribution of respondents. In terms of the respondent's age, the respondents with age range $46-55$ years old are the majority with distribution at $50 \%$. Next, the majority of respondents earned in the range of RM 1000-2000 per month, 30\% earned in the range of income of RM 1001-2000, and 20\% respondents in the range of RM 500 and below. This implied that most of the respondents are low-income fisheries. To maintain privacy, the names of small-scale fishers were assigned as participants 1-10. 


\section{Finding and Discussion}

The finding of this study summarises three major themes as presented in Figure 3.

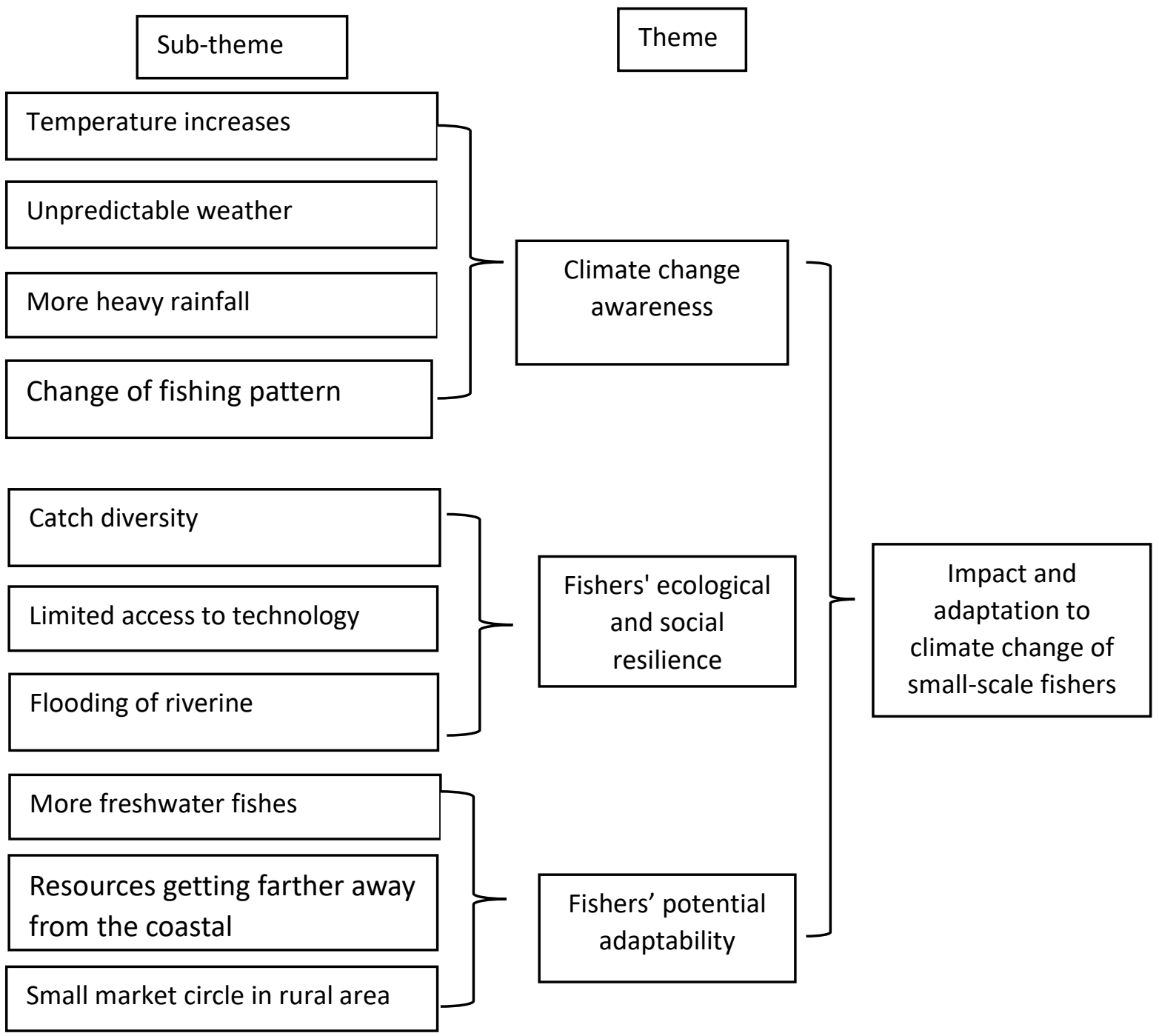

Figure 3. The framework of the impact and adaptation to climate change on small-scale fishers in Kota Belud

\section{Climate Change Awareness}

The first theme focuses on the climate change awareness of small-scale fisheries. The subtheme is related to the increase of temperature, unpredictable weather, heavy rainfall, drought, and flood and also change in fishing pattern. The finding shows that small-scale fisheries are not aware of the impact of climate change on their livelihood. Nonetheless, small-scale fisheries are aware of the increase of temperature, change in the monsoon season as the weather is sometimes unpredicted and there is more heavy rainfall that causes a flood. There is the perception of increases in rain causes flood but also other factors that lead to the flood disaster such as drainage density, flow accumulation, land use, elevation, slope gradient, soil texture, and slope curvature (Roslee \& Norhisham, 2018). On the other hand, the flood disaster in Kota Belud is caused by the earthquakes at Mount Kinabalu that have permanently changed the design of the surrounding environment in the district. An increase in the annual thunderstorm days in Malaysia climate change was foreseen to aggravate high flow in the watershed and caused flooding because the floods usually happen in January, now 
major floods started in October (Daily Express, December 17, 2017). When it is drought, there is no water in the well, most of them still dependent on the tube well. During floods also, it is hard for the fisher's community to find clean water. Both of these situations impacted fisher's community livelihood even though some of them work as small-scale farmers.

Withal, the majority of respondents claimed that the resources are getting farther away from the places they usually go fishing or catch sea produce. So, they have to change their fishing pattern. This either due to a decrease in fish abundance or changes in their distribution (have to go further offshore and/or deeper) (Monnier et al., 2020). Some of the fishers' concerns extracted from the interviews:

A long time ago, all the crabs and clams (Lokan) was very near to the land but now it is very hard to find... we have to go farther... -Participant 6

Long time ago you can catch crabs between 4 to 5 kilos, now it less than 1 kilo...Participant 5

The outcome thus indicates that more awareness is required for the fisher's community, this is to help them prepare for the worse situation during a disaster and adapt to a sustainable livelihood. There is also a need for more studies to predict the direction and consequences of the increasing variability and climate change in Kota Belud (Musinguzi et al., 2015).

\section{Fishers' Ecological and Social Resilience}

There are three fishing communities were selected to test the resilience of their dependency on fishing and these communities have high rates in poverty than another area in Kota Belud. Most of them inclined to catch more towards going inland fish than going out to the sea. This may relate to the higher group of women involve during the interviews. This illustrates that the small-scale women fishers in Kota Belud can sustain themselves and not dependent on their husbands. Through the in-depth study, most of the fishers are very poor and do not have enough fishing gear to go to the sea such as boats and nets (seines, trawls). Half of them are highly dependent to get help from the government to sustain their lives. Another half can make their profit even though it is not much. Extracted from the women's group of smallscale fishers' business:

We have been doing this (catch "bubuk" (small shrimp)) for a long time already, when I started this "belacan" (small-shrimp paste) business we can still see the "bubuk" near the shoreline, but now we cannot see them anymore...-Participant 7

If we not doing the "belacan" we will go catch crabs and shellfish near the shore...Participant 8

Small-scale fisheries play a critical role in both poverty alleviation and food security. During the time of crisis, information and communication were extremely essential. The internet provides an essential link to the weather condition and any emergency updates. However, some of the villagers have a hard time getting through the internet. In the case of some parts of Kota Belud, although all respondents own a mobile phone, they regularly experience a slow and unstable internet connection. Extract from the interviews as follow: 
The internet here is very slow and sometimes there hardly any connection at all... Participant 9

It is very hard, the mobile network also in a certain area is not available... -Participant 10

Without says, information is extremely important amid times of disaster, such as flood disaster. Nonetheless, the information can be used to help the small-scale fishers to prepare for an emergency since some of them generally engaged in seasonal fishing, it is difficult for them to create a sufficiently stocked emergency fund when disaster strike. Extract from the interviews as follow:

It is hard to predict, if raining here at the kampong it won't flood but if it raining uphill here can be flooded...If the seawater is flooding during the heavy rain, here also can be flooded, we only dependent on what we have and sometimes the help from the government... -Participant 2

Due to flash floods that usually happen in Kota Belud, the Sabah state government-issued disaster stimulus measures to ease the burden and difficulties faced by various sections of the community because of the disaster. The government gives a flood disaster supply to the villagers that were affected. The government had an allocation of RM360 million plan to tackle Kota Belud flooding by upgrading drainage and irrigation systems and management of IADA (Integrated Agricultural Development Area) plantation in Kota Belud (Ministry of Agriculture and Food Industries Malaysia, February 20, 2021). The recent flood victims received RM500 flood relief and RM200 worth of food supply was distribute during the COVID-19 pandemic (Patrick, January 15, 2021). While some of the respondents reported received government aid related to the flood disaster, however, most of the respondents felt that the government assistant was not sufficient. One of the respondents stated:

Yes, we do receive some aid during the flood but it is not sufficient... -Participant 9 The flood disaster is pressure to them and the only way for them to survive is through help from the government. Reducing poverty and supporting the population with basic living conditions are a guarantee of better adaptation especially in the light of climate change (Monnier et al., 2020).

\section{Fishers' Potential Adaptability}

In the concept of fishing for the mainland small-scale fishers' have a broader resources dependency because in reality people who working in fishing industries may have more other sources of income thus this group (agriculture, forestry, and fishing) cannot be disaggregated into fishing alone (Camara \& Sanchez, 2019). For some fishers' or/and farmers that susceptible to floods tend to change their resource dependency, for example, some interviewer claimed that during a flood, freshwater fish is easier to catch. Extract from the interview as follows:

Due to flood, there are a lot of freshwater fishes such as Karuk, Puyu, Tepet... Participant 9

I have a small farm, but during the flood, I go fishing for the family and sell it too... Participant 10 
From figure 4, there are five types of catch that the small-scale fishers incline to catch, from the marine fish, seashell, crustacean, freshwater fishes, and others (small-shrimp). Since most of them are women, they tend to catch crustaceans, seashells, and others because they do not have a fishing vessel. Due to this most of their catch can be seen near the shore. Through the interviews, the respondent also shares the type of catch that decreases and increases. Most of the small-scale fishers that catch seashell and small shrimp (others) agree that the produce is decreasing. While the small-scale fishers that live near the flooding area agree that the freshwater fishes are increasing. Extract from the interviews:

I usually go fishing offshore, but when it is flooding I will catch freshwater fish because there are a lot...-Participant 2

\section{Small-scale fishers inclination to catch}

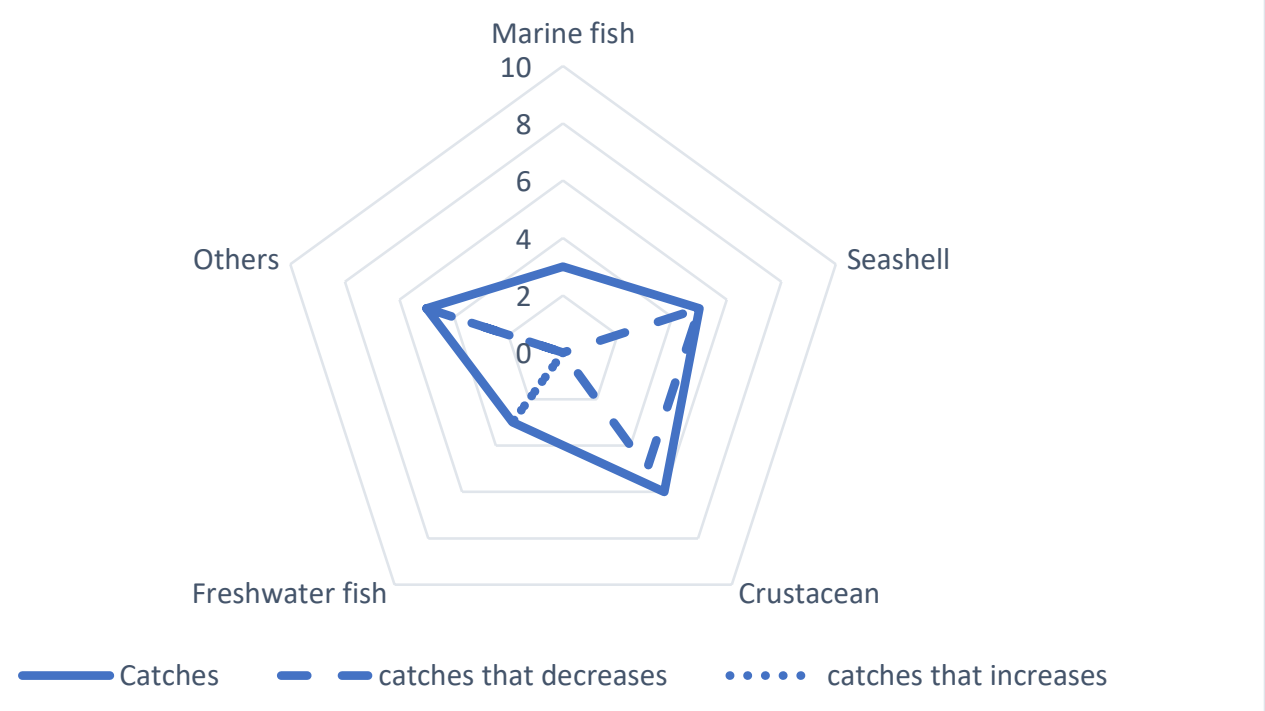

Figure 4. Mean of the scores for the small-scale fishers catch near the coastal area of Kota Belud to see the ecological vulnerability of the fish abundance

It is important for the coastal community, and more broadly, the whole country to adapt to climate change and build resilience in a socio-ecological system. The ecological and social impact of the small-scale fishers' can determine their adaptability to change. Since small-scale fishers (men and women) in this study live in low-income communities. Some adaptation mechanisms may require high costs such as the fishers need to go out further to find fish, changing gear, investing in research, controls or capacity building, building safer landing sites (Monnier et al., 2020). Based on the interview, there is an advantage to the fishers' community during the flood as it is easy for them to catch fish but there is also a drawback of the situation. Most of the small-scale fishers claimed that it is hard for them to market the fish because they have problems accessing the market:

During flooding, there is very limited access to transportation. Moreover, some people chose marine water more than freshwater... Participant 2

Besides, some of the small-scale fishers have their adaptive capacities such as the ability to cope with change, ability to plan, learn and reorganize, and livelihood diversity which indirectly related to the climate change impact. But most of them demonstrates their adaptive weakness such as perception of risk, access to climate technology, information and 
expertise, and financial status. Due to this, is it difficult for them to manage their finances and resources.

\section{Conclusion}

The purpose of this study was to explore the risk and impact of climate change on small-scale fisheries in Kota Belud, Sabah. However, most of them are not prepared socially and economically against the negative impacts of climate change, and few of the small-scale fisheries still highly dependent on government assistant and support. On the other hand, small-scale fisheries still have limited knowledge of climate technology and the adaptation mechanisms for managing their resources sustainably.

The finding in the current study may have several policy implications. First, the local government should plan an adaptation strategy that focuses on mitigating the climate change risks on small-scale fisheries. The adaptation strategy should implement with full consideration not only to the fisheries but the system as a whole. Second, the small-scale fishers should be having access to information on climate change impacts on marine ecosystems, for instance, information about the amplitude of seasonal temperature variability. Third, as poverty and marginalization are primary causes of their vulnerability among the small-scale fisheries, hence the planning should include the capacity building eradicate poverty and provision of food security, particularly for small-scale fisheries. A capacity-building can help to increase the resilience of the small-scale fishery system and reconciling social, economic, and ecological priorities.

\section{Acknowledgment}

We thank YB Isnaraissah Munirah Bt Majilis @ Fakharudy, Charlie Lim Fu Yung, and Anita Samad for the assistance in the focus group discussion.

\section{Corresponding Author}

Dr. Jain Yassin

Faculty of Business and Management, Universiti Teknologi Mara (UiTM) Sabah Branch, Kota Kinabalu, Sabah, Malaysia.

Email: jainyassin@uitm.edu.my

\section{References}

Abbas, S. M., \& Zhiqiang, L. (2020). COVID19, mental wellbeing and work engagement: The psychological resilience of senescent workforce. International Journal of Research in Business and Social Science (2147-4478), 9(4): 356-365.

Azra, M. N., Kasan, N. A., Othman, R., Noor, G. A. G. R., Mazelan, S., Jamari, Z. B., ... \& Ikhwanuddin, M. (2021). Impact of COVID-19 on aquaculture sector in Malaysia: Findings from the first national survey. Aquaculture Reports, 19, 100568.

Beritaharian. (2019). Retrieved 13 April 2021 at https://www.bharian.com.my/hujungminggu/kembara/2019/11/631557/nikmati-keindahan-negeri-di-bawah-bayu

Breen, R. L. (2007). A Practical Guide to Focus-Group Research. Journal of Geography in Higher Education, 30(3): 463-475.

Camara, A., \& Sanchez, R. S. (2019). Economic, Social, and Environmental Impact of a Sustainable Fisheries Model in Spain. Sustainability, 11(6311): 1-16. 
Che Omar, A. R., Ishak, S., \& Jusoh, M. A. (2020). The impact of Covid-19 Movement Control Order on SMEs' businesses and survival strategies. Malaysian Journal of Society and Space, 16(2): 139-150.

Daily Express. (2017). RM167m Plan to Tackle Kota Belud Flooding. Retrieved 14 April 2021 at http://dailyexpress.com.my/news.cfm?NewsID=121710

FAO. (2021). Small-scale fisheries. Retrieved 12 April 2021 at http://www.fao.org/fishery/fishcode-stf/activities/ssf/en

Institute of Development Studies (IDS). (2020) The Impact of Covid-19 and The Movement Control Order (MCO) On the fisheries industry in Sabah. The survey on the impact COVID-19 andbMovement Control Order on Sabah fishing industry 21-27 April 2020. Retrieved 8 April 2021 at https://ids.org.my/main/wpcontent/uploads/2020/05/SURVEY-REPORT-FOR-THE-FISHERIES-INDUSTRY.pdf

Islam, M. M., Islam, N., Habib, A. and Mozumder, M. M. H. (2020). Climate Change Impacts on a Tropical Fishery Ecosystem: Implications and Societal Responses. Sustainability, 12(19): 7970.

Khazanah Research Institute. (2015). Making Housing Affordable. Kuala Lumpur, Khazanah Research Institute, Malaysia.

Khor, M. (2015). Lessons from the Great Flood. The Star Online. Retrieved 14 April 2021 at https://www.thestar.com.my/opinion/columnists/global-trends/2015/01/19/lessonsfrom-the-great-floods/

Kota Belud Liaison Office. (2021). Kota Belud District Profile for All Party Parliamentary Group Malaysia on Sustainable Development Goals.

Magawata, I., \& Ipinjolu, J. K. (2014). Climate change: Mitigation and adaptation strategies in fisheries and aquaculture in Nigeria. Journal of Fisheries and Aquatic Science, 9(4), 257261.

Marshall, N. A., Tobin, R. C., Marshall, P. A., Gooch, M. and Hobday, A.J. (2013). Social Vulnerability of Marine Resource Users to Extreme Weather Events. Ecosystems, 16(5):797-809.

Ministry of Agriculture and Food Industries Malaysia. (2021). Pesawah Terjejas Banjir Di Kota Belud Terima Bantuan Menerusi Mafi Prihatin. Retrieved 14 April 2021 at https://www.mafi.gov.my/documents/20182/269754/Pesawah+Terjejas+Banjir+di+Ko ta+Belud+Terima+Bantuan+Menerusi+MAFI+Prihatin.pdf/fOe2a302-c445-433f-83490959202169b8

Monnier, L., Gascuel, D., Alava, J. J., Barragán, M. J., Gaibor, N., Hollander, F. A., Kanstinger, P., Niedermueller, S., Ramírez, J., \& Cheung, W. W. L. (2020). Small-scale fisheries in a warming ocean: exploring adaptation to climate change. Scientific report. WWF Germany.

Muhammad, M., Idris, K., Ariffin, E. H., Shaffril, H. A. M., Samah, B. A. and Suandi, T. (2016). The Impact of Climate Change on Small-Scale Fishermen in Malaysia. 11(13): 3352-3356.

Mafongoya, P., Naidoo, D., Sibanda, M., \& Muringai, R. T. (2019). Small-scale fishers' perceptions of climate change and its consequences on fisheries: the case of Sanyathi fishing basin, Lake Kariba, Zimbabwe. Transactions of the Royal Society of South Africa, 74(3), 248-257.

Musinguzi, L., Efitre, J., Odongkara, K., Ogutu-Ohwayo, R., Muyodi, F., Natugonza, V., ... \& Naigaga, S. (2016). Fishers' perceptions of climate change, impacts on their livelihoods and adaptation strategies in environmental change hotspots: A case of Lake Wamala, Uganda. Environment, Development and Sustainability, 18(4), 1255-1273. 
Omar, S. Z., Shaffril, H. A. M., Bolong, J., D'Silva, J. L., Abu Hassan, A. (2012). Usage of offshore ICT among fishermen in Malaysia. Journal of Food Agriculture and Environment, 10: 1315-1319.

Patrick, M. (2021). Keluarga Terjejas Banjir, Air Pasang Besar Di Sabah Terima Bantuan RM500. Retrieved 14 April 2021 at https://www.astroawani.com/berita-malaysia/keluargaterjejas-banjir-air-pasang-besar-di-sabah-terima-bantuan-rm500-278001

Ramli, S. A., Omar, S. Z., Bolong, J., Silva, J. L. D., Azril, H. (2013). Influence of behavioral factors on mobile phone usage among fishermen: The case of Pangkor Island Fishermen. Asian Social Science, 9(5): 162-170.

Roslee, R., and Norhisham, M. N. (2018). Flood Susceptibility Analysis using Multi-Criteria Evaluation Model: A Case Study in Kota Kinabalu, Sabah. ASM Sc. J., 11(3): 123-133.

Sabah.edu.my. (2021). Location. Retrieved 8 April 2021 at http://www.sabah.edu.my/itma007/location.htm

Yakin, H. S. M., Totu, A., \& Derak, R. (2016). Simbol Binatang Ternakan dan Konsep Artifak sebagai Manifestasi Identiti Budaya dan Identifikasi Etnik Peribumi Sabah: Satu Kajian dari Perspektif Komunikasi. MANU: Jurnal Pusat Penataran IImu dan Bahasa (PPIB).

Shaffril, H. A. M., Hamzah, A., D'Silva, J. L., Abu Samah, B., Abu Samah, A. (2017). Individual adaptive capacity of small-scale fishermen living in vulnerable areas towards the climate change in Malaysia. Climate and Development, 9, 313-324.

Staples, D., Satia, B., Gardiner, P. R. (2004). A research agenda for small-scale fisheries. Food and Agriculture Organization of the United Nations Regional Office for Asia and the Pacific. RAP Publication.

Yassin, J., Aralas, S., \& Basa, D. E. (2021). Tourism Density Effect on Environmental Performance Index: Evidence in ASEAN Countries. Applied Environmental Research, 43(1), 90-101. 